\title{
STRATEGI TRANSFORMASI HUKUM ISLAM DALAM PEMBINAAN HUKUM NASIONAL
}

\author{
Anwar Sadat \\ Sekolah Tinggi Agama Islam Negeri (STAIN) Majene \\ Email: anwarsadat21@yahoo.co.id
}

\begin{abstract}
This study reviews the strategy of transforming Islamic law in fostering national law. The results of the study show that in general there are two lines of application of Islamic law that can be pursued in efforts to foster national law, namely the path of transformation into the law and nontransformation pathways beyond the prevailing laws.
\end{abstract}

Abstrak: Kajian ini mengulas tentang strategi transformasi hukum Islam dalam pembinaan hukum nasional. Hasil kajian menunjukan bahwa secara garis besar ada dua jalur penerapan hukum Islam yag dapat ditempuh dalam upaya pembinaan hukum nasional yaitu jalur transformasi ke dalam undang-undang maupun jalur non transformasi di luar per-undang-undang-an yang berlaku.

Kata Kunci: hukum, Islam dan transformasi

\section{PENDAHULUAN}

Hukum Islam memiliki kelebihan yang tidak dimiliki oleh undang-undang buatan manusia dalam berbagai segi dan makna. Hukum buatan manusia terbatas pada seperangkat peraturan yang bersifat materiil dan keduniawian semata. Hukum-hukum yang terkandung di dalamnya terbatas kepada memelihara hal-hal yang bersifat lahir saja, tidak ada aspek halal dan haram, tidak ada hal-hal yang bersifat batin dalam hubungannya dengan Khaliq (sang pencipta). Oleh karena itu, jika badan legislatif dan yudikatif lemah atau lembaga hukumnya salah, dan terdakwa terbebas dari tuduhan yang diajukan kepadanya, maka hal tersebut diterima tanpa dosa.

Hukum Islam adalah hukum yang diciptakan untuk memenuhi kebutuhan jasmani dan rohani, dunia dan akhirat. Dalam pelaksanaannya tergantung pada iman dan akhlak, 
2 | Jurnal Syari'ah dan Hukum Diktum, Volume 16, Nomor 1 Juli 2018 : 1 - 15

serta kekuatan dan kekuasaan. Di sisi lain, hukum Islam memberikan balasan dunia dan akhirat. Oleh karena itu, penghormatan dan ketaatan terhadap syariat yang cemerlang ini tidak hanya terbatas pada hukum-hukum yang nasnya bersumber dari al-Qur'an dan sunah saja, tetapi mencakup berbagai hukum hasil ijtihad dan peraturanperaturan lain yang dikeluarkan oleh negara dalam memelihara kemaslahatan umum, seperti peraturan lalu lintas, perpajakan, dan sebagainya. Masyarakat harus menaati peraturan yang dibuat oleh negara. Hal itu termuat dalam QS alNisa'/4: 59:

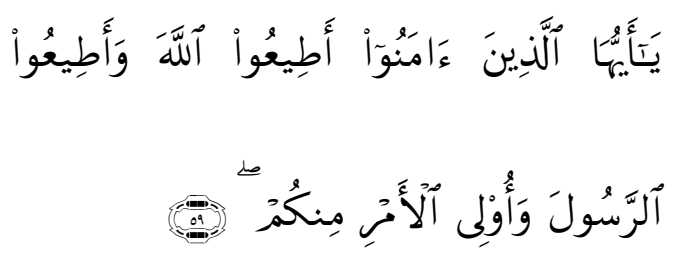

Terjemahnya:

Hai orang-orang yang beriman, taatlah kepada Allah, kepada rasul dan Ulil Amri (pemimpin) di kalangan kamu. ${ }^{1}$
Hukum Islam tidak memiliki keraguan dalam menjaga dan memelihara realita pada setiap aspek kehidupan manusia. Oleh karena itu, hukum Islam bagian dari syariat Islam, maka hukum Islam itu merupakan hukum yang tidak mungkin ada kebatilan di dalamnya. Allah memberikan jaminan bahwa hukum Islam itu sesuai dengan segala kondisi, ruang dan waktu keberadaan manusia. Dalam pelaksanaannya, hukum Islam meniadakan kepicikan, tidak memberatkan, senantiasa memberikan kemudahan dan menjauhkan kesulitan, semua hukumnya dapat dilaksanakan oleh umat manusia. Hukum Islam memperhatikan kemaslahatan manusia dan mewujudkan keadilan yang merata.

Hukum Islam dalam pelaksanaannya memperhatikan aspek akhlak dan moral yang merupakan akibat dari karakteristik ilahiyah. Dengan demikian, hukum Islam memiliki peran untuk 
memajukan umat manusia, menyelamatkan dari tekanan egoistis dan hawa nafsu, melepaskan manusia dari adat-istiadat yang menyimpang dan menjaga keamanan dan ketertiban dengan hal-hal baik serta bermanfaat dengan berpedoman pada akhlak yang mulia. Hukum Islam tidak mengakui pemisahan peraturan perundang-undangan dari akhlak (moralitas), sebagaimana hukum Islam tidak menerima pemisahan antara politik dan ekonomi.

Salah satu fakta yang tidak dapat diingkari adalah bahwa hukum Islam berlaku pada hampir di seluruh dunia dengan kelebihan dan kekurangannya, keragaman bangsa dan peradabannya, sesuai dengan perubahan ruang dan zamannya. Hukum Islam mampu memenuhi berbagai keperluan masyarakat dan mampu mendiagnosis berbagai permasalahan yang timbul dalam kehidupan dengan cara aman, tertib dan adil. Hukum Islam tampil sebagai undang-undang yang diagungkan di negara-negara Islam sekitar 13 abad lamanya sampai datangnya masa imperialisme Barat yang menggantikannya sebagai kanun buatan manusia.

Dari uraian tersebut di atas penulis kemudian ingin mengkaji lebih jauh tentang Strategi Transformasi Hukum Islam dalam Pembinaan Hukum Nasional.

\section{PEMBAHASAN}

\section{Trasformasi Hukum Islam}

Pembacaan yang obyektif yang dihadapi hukum Islam sepanjang sejarah Indonesia adalah sikap tergesa-gesa yang segera menuntut sesuatu yang subtantif sejatinya belum jelas. Sebagian umat Islam menuntut formalisasi dan transformasi hukum Islam sementara agenda pemikiran ulang, pembaruan, dan rekonstruksi hukum Islam yang sesuai dengan realitas masyarakatbangsa Indonesia belum dilakukan secara sungguh-sungguh. Meskipun ada perangkat materil hukum Islam, seperti Kompilasi Hukum Islam (KHI) dan beberapa ketentuan yang ditransformasikan, tetapi 
4 | Jurnal Syari'ah dan Hukum Diktum, Volume 16, Nomor 1 Juli 2018 : 1 - 15

mempertimbangkan kenyataan hukum Islam ke dalam hukum tersebut belum memadai sebagai nasional. ${ }^{2}$ sebuah sistem hukum. Pandangan- Era yang semakin terbuka, pandangan tersebut memerlukan kiranya upaya untuk menata dan strategi dan upaya integrasi hukum memantapkan struktur politik dalam Islam dalam pembinaan hukum nasional.

Strategi dan upaya transformasi hukum Islam bagi pembinaan hukum nasional dilihat dari teori Meier Friedman, tergantung pada tiga komponen sebagai berikut:

\section{A. Komponen struktur}

Struktur politik yang di dalamnya terdapat mayoritas penganut Islam harus memiliki komitmen terhadap keberadaan (eksistensi) dan keefektifan berlakunya hukum Islam di Indonesia. Dengan mengacu kepada kehidupan politik Indonesia pada pasca 1990-an yang ditandai dengan kebijakan-kebijakan pemerintah yang mencerminkan hubungan kemesraan pemerintah dengan umat Islam, maka ada harapan dukungan dari struktur politik untuk mentransformasikan upaya memperjuangkan hukum Islam menjadi hukum nasional, bukan sesuatu yang tabu. Para tokoh Islam harus memiliki kejelian untuk memilih bidang-bidang hukum yang sekiranya tidak bersingunggan berat dengan hukum selain hukum Islam dan kemampuan mereka untuk membawa diri dengan kiat-kiat jitu dan simpatik di arena perjuangan mereka masing-masing. Semangat jihad dan ijtihad dari tokoh Islam perlu ditumbuhkan.

Keberadaan teori pemikiran mengenai penerapan hukum Islam di Indonesia. Menurut Masykuri Abdillah, dilihat dari segi orientasi penerapannya dapat diklasifikasikan menjadi tiga kelompok. Pertama, adalah orentasi yang berupaya memperjuangkan implementasi ajaran secara komprehensif (käffah), baik bidang iman, fikih, maupun 
akhlak. Kedua, adalah orientasi yang hanya berupaya memperjuangkan implementasi akidah dan etika-moral Islam. Ketiga, adalah orientasi yang hanya berupaya memperjuangkan sedapat mungkin implementasi syariah dan akidah serta etika moral atau minimal prinsip-prinsipnya, yang terintegrasi ke dalam sistem nasional. Orentasi pertama menjadikan Islam sebagai ideologis, kedua menjadikan Islam sebagai sumber etika, dan ketiga menjadikan Islam sebagai sub-ideologi. ${ }^{3}$

Orientasi pertama sangat idealistis dalam konteks Islam, tetapi kurang realistis dalam konteks masyarakat dan Bangsa Indonesia yang sangat plural. Orentasi kedua sangat idealistis dalam konteks keindonesiaan, tetapi kurang realistis dalam konteks Islam, yang ajarannya tidak memisahkan antara agama dan negara. Tarikan yang kuat terhadap salah satu orientasi mengakibatkan semakin kuatnya tarikan ke arah orientasi yang berlawanan, dan bahkan akan menimbulkan konflik internal yang sangat besar. Oleh karena itu, diperlukan jalan tengah di antara keduannya, yakni menjadikan Islam sebagai sub-ideologi bagi Pancasila. $^{4}$

Orientasi ketiga ini lebih realistis dan moderat, meskipun diusahakan sedapat mungkin melaksanakan hukum Islam atau prinsip-prinsipnya dalam kehidupan berbangsa dan bernegara. Pandangan tersebut tetap mengakui Pancasila sebagai ideologi negara. Orientasi ini mendukung pendekatan kultural dan sekaligus struktural dengan cara yang konstitusional dan demokratis. Pengupayaan implementasi sistem alternatif yang islami, meskipun tidak bersifat struktural, seperti perbankan Islam, asuransi Islam, dan lain-lain.

Reinterpretasi ajaran Islam yang lebih mengakomodasi kemajemukan diperlukan untuk mendukung orientasi ketiga. Interpretasi yang dimaksud tidak hanya berbentuk interpretasi formalistik, tetapi harus disertai 
6 Jurnal Syari'ah dan Hukum Diktum, Volume 16, Nomor 1 Juli 2018 : 1 - 15

dengan interpretasi filosofis dan bidang hukum tertentu, perlu sosiologis. Artinya pemahaman pengategorian hukum Islam yang keagamaan tidak hanya berdasarkan dapat bertranformasi ke dalam teks-teks formal, tetapi juga melihat kondisi sosio-kultural masyarakat bangsa Indonesia serta filosofi ajaran Islam itu sendiri, yakni untuk kemaslahatan, keadilan, dan rahmat bagi umat manusia. Kondisi masyarakat yang perlu diperhatikan adalah kemajemukan, baik dari segi agama maupun tingkat penghayatan keagamaan, sementara tingkat pendidikan dan ekonomi masyarakat secara umum masih rendah. Tentu produk dari penafsiran seperti ini suatu saat bisa berubah jika kondisi sosio-kultural itu mengalami perubahan.

\section{B. Komponen Subtansi}

Subtansi hukum Islam yang diangkat kedalam hukum nasional perlu pengkajian lebih mendalam. Pengkajian tersebut tidak mudah, karena luasnya cakupan (materi) hukum Islam yang dikaji. Oleh karena itu, sebelum mengkaji bidang-

hukum nasional.

Pengkajian subtansi diarahkan pada aspek dinamikanya dalam rangka beradaptasi dengan hukum nasional yang di dalamnya mengandung unsur keragaman dan keberagaman. Subtansi hukum Islam yang dinilai kaku oleh sebagian kalangan, bahkan mungkin menakutkan karena sikap absolut pemeluknya, perlu dikaji lebih serius agar lebih bersifat terbuka dan kontekstual, dalam arti terbuka bagi penafsiran baru yang lebih sesuai dengan konteks sosial keindonesiaan dan kekinian, sehingga hukum Islam akan integrated dalam hukum nasional bukan separated.

Peranan ijtihad menjadi sangat penting. Persoalannya adalah siapa atau lembaga mana yang representatif untuk mengkaji? Pertanyaan ini penting, karena seringkali pengkajian yang dilakukan oleh kelompok yang kurang 
representatif dianggap kurang valid sehingga kurang ditaati oleh masyarakat. Hal itu menyangkut kepentingan umat secara menyeluruh, maka kajiannya perlu melibatkan banyak pihak yang berkompeten dan ijtihadnya dilakukan secara kolektif (jamā'̂̄) dengan pendekatan-pendekatan interdisipliner sehingga hasilnya lebih komprehensif. ${ }^{5}$

Ijtihad kolektif (jamā'ī) bila didukung dengan fasilitas-fasilitas kenegaraan tanpa mengurangi kebebasan para mujtahid, akan lebih berhasil. Lembaga-lembaga ijitihad berwawasan internasional sangat diperlukan, guna memecahkan masalah-masalah bersama, sesuai tuntutan ruang dan waktu, sepanjang masih dalam kerangka syariat Islam. Jika ijtihad kolektif tersebut berhasil digalakkan, maka implikasinya nanti akan baik bagi prospek pelaksanaan hukum Islam di masa depan, sehingga hukum Islam tampak cerah dan tampil untuk menjawab tantangan zaman.
Betapapun dalam praktiknya transformasi bukan kecenderungan, namun pengembangan hukum Islam melalui proses transformasi tetap perlu dilakukan. Hanya masalah materi hukumnya yang perlu dipertimbangkan. Misalnya (a) materi hukumnya bukan di bidang hukum publik, karena dikhawatirkan menimbulkan benturan dengan materi hukum agama lain; (b) materi hukum privat tidak pada semua bidang karena ada bidang-bidang hukum yang sangat peka. Jika bidang hukum yang peka ini diangkat akan menjadi konflik, baik eksternal maupun internal. Jika dilihat dari perkembangan dan kebutuhan dewasa ini dalam kancah pergaulan hukum nasional dan hukum internasional, maka transformasi merupakan tuntunan obyektif dan urgen karena akan mendukung implementasi hukum Islam secara pasti dan mengikat secara formal yuridis. Dengan lahirnya UU Nomor 7 tahun 1989 tentang Peradilan Agama yang telah diubah dengan UU Nomor 3 
8 Jurnal Syari'ah dan Hukum Diktum, Volume 16, Nomor 1 Juli 2018 : 1 - 15

tahun 2006 tentang Pelaksana atas

UU Nomor 7 tahun 1989 dan Inpres

Nomor 1 Tahun 1991 tentang

Kompilasi Hukum Islam, usaha

pembinaan dan pengembangan

hukum Islam dapat dilakukan melalui

peningkatan peranan hakim peradilan

agama, karena profesi hakim itu

sendiri dalam tradisi Islam

merupakan tradisi mujtahid. Hakim

peradilan agama berpeluang besar

untuk menemukan, merumuskan, dan

menetapkan hukum dalam praktik di

lingkungan lembaga peradilan. Hal

itu sejalan dengan yang tersirat

dalam pasal 27 UU Nomor 14 Tahun

1970 tentang Ketentuan Pokok

Kekuasaan Kehakiman yang diganti

dengan UU Nomor 4 Tahun 2004

tentang Kekuasaan Kehakiman,

sebagai penegak hukum dan keadilan

wajib menggali dan memahami nilai-

nilai hukum yang hidup dalam

masyarakat. Kewajiban tersebut secara implisit mengandung hak otonom dan kewenangan para hakim untuk melakukan kerja intelektual dan berijitihad dalam rangka menerapkan hukum Islam dalam praktik peradilan. Kewenangan peradilan agama meskipun masih terbatas, namun jika para hakim menempatkan diri sebagai pekerjapekerja intelektual yang dilakukan secara profesional dalam kapasitas sebagai mujtahid, maka putusan hakim itu dapat dijadikan rujukan bagi keputusan-keputusan berikutnya. ${ }^{6}$ Dengan demikian, terbentuk hukum Islam yang kontekstual, dapat dipraktikkan, bukan hukum di atas kertas (tekstual) seperti yang ada selama ini.

Secara sosiologis, terdapat empat wilayah peta hukum modern sebagai berikut:

1. Hukum negara yang berada di wilayah fungsi legislatif dan eksekutif (Qanun)

2. Hukum hakim yang berada di lembaga peradilan ( qada)

3. Hukum para ahli hukum yang berada di dunia ilmiah dan perguruan tinggi (fikih dan fatwa). 
4. Hukum yang hidup dalam praktik kemasyarakatan ('urf)

Di Indonesia, keempat jenis tersebut cenderung berjalan sendirisendiri dengan dinamikanya masingmasing. Suasana seperti itu tidak banyak mendukung bagi upaya pemgembangan hukum Islam dalam konteks pembinaan hukum nasional. Oleh karena itu, sudah saatnya keempat wilayah hukum tersebut bekerjasama dalam pendekatan saling mengisi.

Kompilasi Hukum Islam merupakan salah satu wujud kerjasama berpikir (jitihad) yang baik antara tokoh-tokoh Islam yang ada di berbagai wilayah hukum, khususnya di wilayah eksekutif (Kementerian Agama), di peradilan (Mahkamah Agung), di perguruan tinggi (UIN, IAIN, STAIN-PTAIS), dan di masyarakat (kiyai dan ulama). Model kerja sama seperti yang terjadi dalam proses pembentukan KHI tersebut kiranya dapat dijadikan tonggak sejarah sekaligus pengalaman berharga bagi upaya pengembangan hukum Islam dalam konteks pembinaan hukum nasional.

\section{Komponen Kultur}

Keberlakuan hukum Islam dalam kancah hukum nasional ditentukan pula oleh pendukung hukum Islam yang memiliki kesadaran untuk menerima dan melaksanakannya. Kenyataan menunjukan bahwa pemeluk Islam sebagai pendukung berlakunya hukum Islam baru merupakan potensi, belum merupakan basis sosial yang efektif. ${ }^{8}$

Sikap umat Islam yang belum mendukung bagi berlakunya hukum Islam dalam pembinaan hukum nasional tersebut perlu segera dibenahi secara lebih intensif. Upaya menasionalisasi hukum Islam di kalangan pemeluk Islam sebagai penduduk mayoritas masih diusahakan agar umat Islam mempunyai kesadaran hukum Islam yang tinggi yang akhirnya diharapkan mematuhinya.

Mukhlas Hisyam menawarkan empat tahap prakondisi transformasi 
10 | Jurnal Syari'ah dan Hukum Diktum, Volume 16, Nomor 1 Juli 2018 : 1 - 15

hukum Islam untuk mendukung upaya tersebut seperti yang dikutip oleh Topo Santoso, yaitu: Pertama, pencegahan melalui aspek akidah atau iman karena keimanan membuat seseorang merasa terawasi oleh Tuhannya. Sehingga umat Islam mampu melakukan self control terhadap yang dilakukan. Hal ini dapat dibuktikan dengan rendahnya angka kejahatan di negara-negara muslim dibandingkan dengan negaranegara maju. ${ }^{9}$

Kedua, pencegahan dari aspek ibadah. Ibadah-ibadah yang diwajibkan oleh agama, jika dilakukan dengan baik akan berdampak positif bagi pelakunya, sebagimana firman Allah dalam QS al-Ankabut/29: 45

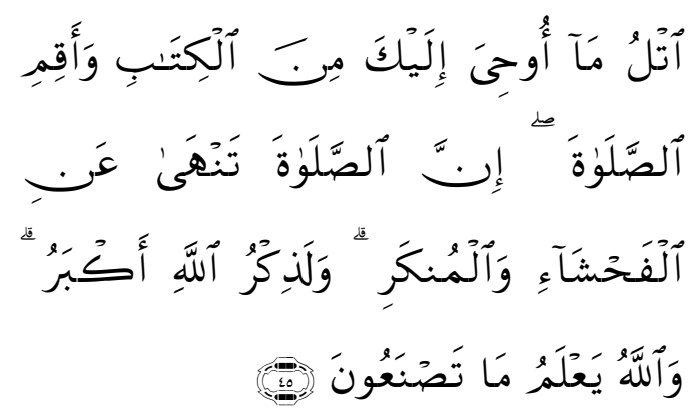

Terjemahnya:

Bacalah apa yang telah diwahyukan kepadamu, yaitu al-
Kitab (al-Qur'an) dan dirikanlah salat. Sesungguhnya salat itu mencegah dari (perbuatanperbuatan) keji dan mungkar. Dan sesungguhnya mengingat Allah (salat) adalah lebih besar (keutamaannya dari ibadatibadat yang lain). Dan Allah mengetahui apa yang kamu kerjakan. ${ }^{10}$

Sekalipun tidak ada atau belum ada data tentang ibadah para pelaku kejahatan, tetapi dalam kenyataanya kejahatan lebih banyak dilakukan oleh mereka yang tidak memperdulikan salat dan ibadah lainnya.

Ketiga, pencegahan dari segi keadilan sosial. Maksudnya, setiap warga negara diberikan kesempatan yang mudah untuk memenuhi kebutuhannya dengan cara yang halal dan tertutup di hadapannya kesempatan untuk berbuat yang tidak halal. Pencegahan tahap ketiga ini, dijadikan syarat keberlakuan hukum pidana Islam oleh Khalifah Umar bin Khattab ra., ketika terjadi krisis di zamannya dan banyak warga yang kelaparan. Umar tidak memberlakukan hukuman potong 
tangan bagi pencuri untuk sementara.

Keempat, pencegahan dari segi amar makruf dan nahi munkar yang seharusnya menjadi budaya di kalangan masyarakat muslim, karena merupakan titik sentral dari semua ajaran agama. $^{11}$

Sifat pilihan hukum kewenangan pengadilan agama dalam masalah masalah kewarisan bagi orang-orang Islam dapat digunakan sebagai uji coba bagi tingkat kesadaran masyarakat muslim, karena efektifitas berlakunya hukum kewarisan Islam bukan ditentukan oleh struktur hukum (pengadilan), namun sangat tergantung pada kulturnya. Jika hukum kewarisan Islam membudaya di kalangan pemeluk Islam, akan diterapkan hukum kewarisan Islam secara efektif. Demikian pula dengan bidang-bidang hukum yang lainnya.

Hukum Islam berfungsi secara efektif dalam masyarakat harus melalui proses pelembagaan (institusionalization), agar hukum Islam menjadi bagian dari suatu lembaga sosial. Pelembagaan yakni suatu proses ketika norma-norma hukum Islam dapat diketahui, dipahami, dinilai, dihargai, dijiwai dan ditaati oleh sebagian besar masyarakat. Masyarakat akan menghargai dan mentaati hukum Islam apabila hukum benar-benar menjamin kemaslahatan hidup mereka di dunia dan di akhirat, ketenteraman, kedamaian, dan kesejahteraan lahir dan batin, baik secara individu maupun sosial. ${ }^{12}$ Dengan kata lain, hukum Islam harus mampu memfasilitasi manusia dalam memenuhi kebutuhan-kebutuhan hidupnya. Sosok hukum Islam seperti ini juga sangat ditentukan oleh "subtansinya," karena itu untuk dapat memperoleh dukungan kultur, maka subtansinya perlu dibenahi lebih dahulu.

Apabila upaya pembinaan dan pengembangan hukum Islam di Indonesia melalui jalur transformasi mengalami hambatan-hambatan, maka alternatifnya dapat ditempuh melalui jalur non transformasi. 
12 | Jurnal Syari'ah dan Hukum Diktum, Volume 16, Nomor 1 Juli 2018 : 1 - 15

Untuk kondisi Indonesia, menurut jalur transformasi melalui Warkum Sumitro, alternatif non perundang-undangan nasional dan transformasi lebih memungkinkan nontransformasi yang berkembang di karena beberapa alasan: Pertama, luar perundang-undangan nasional.

tidak terkesan "dominasi mayoritas" karena wujudnya tidak menempatkan

Di antara dua jalur tersebut, kecenderungan kedua, yakni label Islam, cukup memasukan nilainilai yang dianggap prinsip. Kedua, dukungan dari struktur politik tidak perlu dilakukan dengan terangterangan sehingga yang berperan adalah suara hati nurani. Artinya, komitmen para tokoh Islam yang ada distruktur terhadap perjuangan nilainilai keislaman (hukum Islam) sangatlah penting. Ketiga, persoalan bentuk dan proses bukan merupakan hal yang penting. Hal yang penting masalah subtansi. Keempat, karena bentuk dan proses tidak terlalu penting, maka bisa dilakukan terhadap bidang hukum di sekitar publik dan dalam hal ini lebih startegis. $^{13}$

Dengan demikian, kecenderungan model pengembangan hukum Islam di Indonesia berlangsung melalui dua jalur, yaitu perkembangan hukum Islam di luar perundang-undangan lebih banyak daripada melalui jalur transformasi. Hal ini terjadi karena proses transformasi hukum Islam di Indonesia selalu menghadapi kendala struktural dan kultural baik secara internal maupun eksternal. ${ }^{14}$ Secara Internal, para pendukung sistem hukum Islam belum tentu beranggapan bahwa hukum Islam itu sebagai suatu sistem yang belum final, perlu dikembangkan dalam konteks hukum nasional. Sedangkan kendala eksternal yakni struktur politik yang belum tentu mendukung proses transformasi hukum Islam. Dengan dukungan tiga komponen tersebut, yakni komponen struktur, komponen subtansi, dan komponen kultur dengan berbagai persyaratan, hukum Islam akan mempunyai posisi 
tawar yang tinggi dalam proses transformasi bagi pembinaan hukum nasional. Apabila jalur nontransformasi dipilih sebagai alternatif dengan berbagai keuntungan seperti diuraikan sebelumnya, maka yang menjadi garapan umat pada masa-masa mendatang tidak saja pada bidangbidang hukum privat, tetapi juga bidang hukum yang menyangkut sektor publik, misalnya hukum pidana, hukum ketatanegaraan, hukum lingkungan hidup, hukum ekonomi dan lain-lainya yang menjadi kecenderungan dari tuntutan arus globalisasi. Dengan strategi dan upaya di atas, hukum Islam akan mampu berintegrasi bagi pembinaan hukum nasional.

\section{Penutup}

Kesimpulan dari pembahasan bahwa strategi transformasi hukum Islam dalam pembinaan hukum nasional dapat melalui dua jalur yaitu:

Transformasi dan non transformasi. Jalur transformasi meliputi tiga tahap yaitu: Pertama, adalah orentasi yang berupaya memperjuangkan implementasi ajaran secara komprehensif (kaffah), Kedua, adalah orientasi yang hanya berupaya memperjuangkan implementasi akidah dan etika-moral Islam. Ketiga, adalah orientasi yang hanya berupaya memperjuangkan sedapat mungkin implementasi syari'ah di samping akidah serta etika moral atau minimal prinsipprinsipnya, yang terintegrasi ke dalam sistem nasional.

Adapun non transormasi yakni jalur perkembangan hukum Islam di luar perundang-undangan. Hal ini terjadi karena proses transformasi hukum Islam di Indonesia selalu menghadapi kendala struktural dan kultural baik secara internal maupun eksternal. Jalur kedua ini lebih bersifat lokal dan terbatas namun akan menjadi sangat efektif dalam memulai proses secara perlahan. 


\section{Catatan Akhir:}

${ }^{1}$ Departemen Agama RI., Al-Qur'an dan Terjemahnya (Jakarta: Proyek Pengadaan Kitab Suci al-Qur'an, 2002), h. 128.

${ }^{2}$ Menurutnya, dalam sebuah negara yang menerapkan sistem hukum, paling tidak harus ada tiga komponen yang dijadikan dasar atau pondasi agar sistem hukum negara tersebut kuat. ketiga komponen tersebut adalah: Legal sructure, Legal Subtance, dan Legal culture. Lihat, Meirer Friedman, American Law: an Intruduktion (Cet. II; New York: W.W. Norton \& Company, 1998), h. 21.

${ }^{3}$ Lihat Abdillah, Masykuri, at. al., Formalisasi Syari'at Islam di Indonesia; Sebuah Pergulatan Yang Tak Pernah Tuntas (Cet. I; Jakarta: Renaisan, 2005), h. 319.

${ }^{4}$ Secara teoretis sebuah ideologi itu harus memenuhi tiga dimensi, yakni dimensi pencerminan terhadap realitas, dimensi idealisme yang memberikan inspirasi bagi warga masyarakat dalam bertindak, dan dimensi fleksibilitas yang memungkinkan adanya interpretasi dari berbagai pandangan. dalam konteks terakhir ini, agama-agama atau aliran-aliran politik yang ada bisa menjadi sub-ideologi Pancasila, sehingga ia benarbenar menjadi ideologi terbuka, yang bisa menerima berbagai interpretasi sesuai dengan latar belakang budaya masingmasing kelompok ini. Lihat, Maskuri Abdillah, Ibid h. 322-323. Lihat lebih Lanjut pada Anwar Sadat, K.H. Ali Yafie dan Metamorfosa Hukum Islam, Cet I, Makassar, Alauddin university Press, 2013.

${ }^{5}$ Dalam ijtihad jama $i$ ini, ilmuwan dari berbagai disiplin ilmu, berkumpul dan berbagai permasalahan yang telah diagendakan terutama hal-hal yang bercorak umum dan penting bagi umat manusia. Disini, yang berfungsi sebagai majelis atau jamaahnya, bukan individu, karena itu apa yang tidak tepenuhi oleh salah satu anggotanya, telah terwakili oleh yang lain, karena itu Ijtihad dalam hukum Islam harus dilakukan secara jama'i (bersama-lama). Lihat, Ahmad Azhar Basyir, et.al, Ijitihad dalam Sorotan (Cet, IV;
Bandung: Mizan 1996), h. 62. Lihat. Anwar Sadat, K.H. Ali Yafie dan Metamorfosa Hukum Islam, Cet I, Makassar, Alauddin university Press, 2013.

${ }^{6}$ Lihat, Muhammad Daud Ali, "Pengembangan Hukum Islam dan Yurisprudensi Peradilan Agama," Mimbar Hukum No. 13 (1994), h.18.

213.

${ }^{7}$ Lihat Warkum Sumitro, op. cit., h.

${ }^{8}$ Fadjar, A. Mukthie, "Trarformasi Hukum Syariat ke dalam Hukum Nasional," Makalah, Pondok Gontor, 1991, h. 7. Lihat lebih lanjut pada Anwar Sadat, K.H. Ali Yafie dan Metamorfosa Hukum Islam, Cet I, Makassar, Alauddin university Press, 2013

${ }^{9}$ WHO mencatat pada tahun 1985 ada 32 juta pencadu narkotika yang sebagian besar tersebar di negara-negara maju. Amnesti Internasional juga mencatat angka kejahatan di negara-negara Barat yang selalu meningkat. Di tahun 1987, tercatat 45.000 penodongan di negara sekecil Inggris. Sementara itu perdagangan anak kecil yang dipelopori oleh sindikat negara-negara nonmuslim, terutama Israel, mencapai rata-rata satu juta anak setiap tahunnya. Ini menunjukan bahwa keimanan yang dimiliki masyarakat negara-negara muslim relatif masih dapat membendung kenaikan angka kejahatan. Topo Santoso, op. cit., h. 96-97. Lihat lebih lanjut pada Anwar Sadat, K.H. Ali Yafie dan Metamorfosa Hukum Islam, Cet I, Makassar, Alauddin university Press, 2013

${ }^{10}$ Kementerian Agama RI., Al-Qur'an dan Terjemahnya (Jakarta: Yayasan Pentafsir dan Penterjemah Al-Qur'an, 2008) h. 635

${ }^{11}$ Berdasarkan penelitian yang dilakukan oleh Schwarz dan Sonya Orleans. bahwa untuk mengukur mana yang lebih efektif, yakni penanaman kesadaran atau ancaman hukuman yang tinggi terhadap efektifitas sanksi, khususnya terhadap kepatuhan untuk membayar pajak. Dari hasil penelitian tersebut diperoleh kesimpulan, bahwa sanksi lebih efektif bagi mereka yang berasal dari kelas sosial yang relatif tinggi (dari sudut 
kedudukan ekonomi). Bagi masyarakat luas yang menduduki kelas sosial yang lebih rendah, maka penanaman kesadaran jauh lebih efektif daripada ancaman-ancaman hkum, dikutip oleh, Soerjono Soekanto, Faktor-Faktor Yang Mempengaruhi Penegakan Hukum (Cet. V; Jakarta: Raja Grafindo Persada, 2004), h. 66. Lebih lengkap Lihat. Anwar Sadat, K.H. Ali Yafie dan Metamorfosa Hukum Islam, Cet I, Makassar, Alauddin university Press, 2013

${ }^{12}$ Lihat Sjechul Hadi Parmono, Mimbar Hukum, III, No. 5 (1992), h. 9.

${ }^{13}$ Lihat Warkum Sumitro, Perkembangan Hukum Islam di Tengah Kehidupan sosial Politik di Indonesia (Cet. I; Malang: Bayumedia, 2005), h. 214-215.

${ }^{14}$ Lihat Jimly Asshidieqe, Majalah Pesantren, VIU, No. 2 (1990), h. 14. dalam Warkum Sumitro, op. cit., h. 210.

\section{DAFTAR PUSTAKA}

Kementerian Agama RI., Al-Qur'an dan Terjemahnya Jakarta: Proyek Pengadaan Kitab Suci al-Qur'an, 2002.

Anwar Sadat, K.H. Ali Yafie dan Metamorfosa Hukum Islam, Cet I, Makassar, Alauddin university Press, 2013.

Departemen Agama RI., Al-Qur'an dan Terjemahnya, Jakarta: Proyek Pengadaan Kitab Suci al-Qur'an, 2002.

Meirer Friedman, American Law: an Intruduktion (Cet. II; New York: W.W. Norton \& Company, 1998.

Abdillah, Masykuri, at. al., Formalisasi Syari'at Islam di Indonesia; Sebuah Pergulatan Yang Tak Pernah Tuntas, Cet. I; Jakarta:
Renaisan, 2005.

Ahmad Azhar Basyir, et.al, Ijitihad dalam Sorotan. Cet, IV; Bandung: Mizan 1996.

Muhammad Daud Ali, "Pengembangan Hukum Islam dan Yurisprudensi Peradilan Agama," Mimbar Hukum No. 13, 1994.

Fadjar, A. Mukthie, "Trarformasi Hukum Syariat ke dalam Hukum Nasional," Makalah, Pondok Gontor, 1991.

Departemen Agama RI., Al-Qur'an dan Terjemahnya, Jakarta: Yayasan Pentafsir dan Penterjemah Al-Qur'an, 2008.

Soerjono Soekanto, Faktor-Faktor Yang Mempengaruhi Penegakan Hukum, Cet. V; Jakarta: Raja Grafindo Persada, 2004.

Sjechul Hadi Parmono, Mimbar Hukum, III, No. 51992.

Warkum Sumitro, Perkembangan Hukum Islam di Tengah Kehidupan sosial Politik di Indonesia, Cet. I; Malang: Bayumedia, 2005.

Jimly Asshidieqe, Majalah Pesantren, VIU, No. 2/ 1990. 